\title{
Benzocaine and clove oil as anesthetics for pejerrey (Odontesthes bonariensis) fingerlings
}

\author{
[Benzocaina é óleo de cravo como anestésicos para alevinos de \\ peixe-rei (Odontesthes bonariensis)] \\ J. Morato-Fernandes ${ }^{1}$, R.A. Tavares ${ }^{1}$; C. B. Rocha ${ }^{1}$, J.L.O.F. Pouey ${ }^{2}$, S.R.N. Piedras ${ }^{2 *}$ \\ ${ }^{1}$ Aluno de pós-graduação - FAEM - Universidade Federal de Pelotas, RS \\ ${ }^{2}$ FAEM - Universidade Federal de Pelotas, RS
}

\begin{abstract}
Pejerrey (Odontesthes bonariensis) is a native species from Rio Grande do Sul, Uruguay and Argentina where it is of great economic importance for artisanal fishing. One difficulty in laboratory research with pejerrey is related to its sensitivity, as it presents higher basal cortisol levels than other freshwater species. For this reason, the aim of this work was to evaluate the efficiency of benzocaine and clove oil as anesthetics for pejerrey fingerlings. Two experiments were done where fingerlings $(57 \pm 7.8 \mathrm{~mm}$ and $1.1 \pm 0.44 \mathrm{~g}$ ) were exposed to benzocaine with concentrations between $40 \mathrm{mgL}^{-1}$ and $120 \mathrm{mgL}^{-1}$ and to clove oil with concentrations between $12 \mathrm{mgL}^{-1}$ and $75 \mathrm{mgL}^{-1}$. Survival, anesthesia induction time and recovery time for each pharmaceutics were evaluated. Both benzocaine and clove oil pharmaceutics showed efficiency as anesthetics for pejerrey fingerlings, with negative correlation between the dose of anesthetics and the anesthesia induction time. For benzocaine, the concentrations between $80 \mathrm{mgL}^{-1}$ and $100 \mathrm{mgL}^{-1}$ showed better results, as for clove oil the optimal concentrations were between $25 \mathrm{mgL}^{-1}$ and $50 \mathrm{mgL}^{-1}$. On the other hand, the anesthesia recovery time did not present significant variation on the different concentrations of the tested products. The tested products are highly metabolizable by pejerrey.
\end{abstract}

Keywords: anesthesia, survival, induction, recovery, aquaculture

\section{RESUMO}

O peixe-rei (Odontesthes bonariensis) é uma espécie nativa do Rio Grande do Sul, Uruguai e Argentina, onde tem grande importância econômica para a pesca artesanal. Uma dificuldade da pesquisa em laboratório com peixe-rei está relacionada à sua sensibilidade, pois apresenta níveis basais de cortisol mais elevados que outras espécies de água doce. Este trabalho avaliou a eficiência da benzocaína e do óleo de cravo como anestésicos para alevinos de peixe-rei. Foram realizados dois experimentos em que

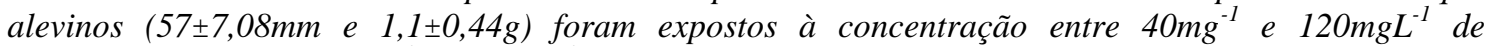
benzocaína e entre $12 \mathrm{mgL}^{-1}$ e $75 \mathrm{mgL}^{-1}$ de óleo de cravo. Avaliaram-se a sobrevivência, o tempo de anestesia e o tempo de recuperação para cada um dos fármacos. Ambos os fármacos, benzocaína e óleo de cravo, mostraram eficiência para anestesiar peixe-rei, com correlação negativa entre a dose e o tempo de indução de anestesia. Para benzocaína, concentrações entre $80 \mathrm{mgL}^{-1}$ e $100 \mathrm{mgL}^{-1} \mathrm{mostraram}$ melhor resultado, enquanto para óleo de cravo as melhores concentrações ficaram entre $25 \mathrm{mgL}^{-1} e$ $50 \mathrm{mgL}^{-1}$. Por outro lado, o tempo de recuperação do estado de anestesia não apresentou variação significativa nas diferentes concentrações testadas. $O$ peixe-rei tem elevada capacidade de metabolização dos produtos testados.

Palavras-chave: anestesia, sobrevivência, indução, recuperação, aquicultura

Recebido em 18 de maio de 2012

Aceito em 15 de março de 2013

*Autor para correspondência (corresponding author)

E-mail: moratofernandes@hotmail.com 


\section{INTRODUCTION}

The use of native species in aquaculture has a number of advantages, mainly because they do not present environmental constraints, are adaptable to local climate and there is already a consumer market. Of the many native species (traíra, jundiá, peixe-rei, lambari, pintado, viola, cascuda, grumatã, piava e cará) from Rio Grande do Sul with the potential for fish farming, the most studied are jundiá (Rhamdia quelen) and pejerrey (Odontesthes bonariensis) (Baldisserotto, 2009).

Pejerrey has been the subject of studies related to reproduction and bio-ecology, however there are few studies related to its handling techniques, due its sensitivity caused by higher basal cortisol levels than other freshwater species (Tsuzuki et al., 2001), which hinders laboratory research.

The handling of fish during the biometrics, classification, transport, artificial breeding and other procedures has increased stress levels that result in injuries and immunologic depletion that can lead to stunted growth, infections and even death. Moreira and Volpato (2004) claim that stress is a factor more responsible for the occurrence of disease and mortality in aquaculture, and in fish the recovery from a mnemonic stressful experience induces increased plasma levels of cortisol.

In contrast, Galhardo and Oliveira (2006) argue that stress situations in fish may be reversed by increasing fear response through the administration of analgesics. Moreover, the Federal Law No.11,794, 2008 that provides for the maintenance of an institutional national database of the Ethics Committees of Animal Use (CEUAs) (Brazil, 2008), has led to greater severity in conducting scientific research using animals, outlining handling standards, which in turn are not known for many species.

In this sense this study aims to evaluate two anesthetics, which allow the appropriate handling of Odontesthes bonariensis fingerlings.

\section{MATERIALS AND METHODS}

Ninety Odontesthes bonariensis fingerlings with average total length of $57 \pm 7.08 \mathrm{~mm}$ and average weight $1.1 \pm 0.44 \mathrm{~g}$ randomly selected from a population of 1,000 animals, stored separately in 1,000 liter polyethylene boxes were used. The entire population was subjected to fasting for 24 hours before the experiment.

The drugs were previously diluted in ethanol at a concentration of $10 \mathrm{~g} 0.1 \mathrm{~mL}^{-1}$ and then placed in a volumetric flask, which had its volume completed to 1.0 liter with distilled water, and this product with a final concentration of $10 \mathrm{mgL}^{-1}$ was the stock solution used to establish the desired concentrations.

Before the final exposure, preliminary tests were performed when concentrations were between 10 and $200 \mathrm{mgL}^{-1}$ of the products for subsequent establishment of the experimental concentrations.

Exposure to anesthetics was adapted from Ross and Ross (1999, 2008) and held in plastic containers with a capacity of two liters of water. Two experiments were conducted with a completely randomized design, where the experimental unit was an individual. In the first experiment five treatments with benzocaine at concentrations of 40,60, 80, 100 and $120 \mathrm{mgL}^{-1}$, with ten replicates per treatment were tested. In the second experiment four treatments with clove oil at concentrations of $12,25,50,75 \mathrm{mgL}^{-1}$, also with ten replicates per treatment were tested.

For each anesthetic concentration, ten individual animals were exposed and the time that each animal reached the third stage of anesthesia (total loss of equilibrium) proposed by Ross and Ross (2008) was evaluated. After reaching the desired stage of anesthesia, fish were removed from the anesthetic solution, measured in length and weight and then kept in a 20 liter tank, containing 18 liters of water with constant aeration to determine the recovery time.

The recovery time of the anesthesia state was measured from the removal of the fingerling from anesthetic until its full recovery, including the time that it remained out of the water for the biometric implementation. The two times were not measured separately. The animals were considered recovered when they resumed swimming movement and balance, as described for Stage four by Ross and Ross (2008). The fish were kept in aquaria to recover for 96 hours to assess mortality. 
The physical and chemical environmental conditions in anesthesia and recovery tanks were monitored. Temperature and dissolved oxygen were measured by oxymeter YSI-F-150, $\mathrm{pH}$ and alkalinity with pot Alfakit by titration (Apha, 1998). The time to reach the stage of anesthesia with the different products and doses tested were analyzed by regression. The anesthesia recovery time data were subjected to variance analysis and showed no significant difference. Analyses were performed by the Statistic 5.0 ${ }^{\circledR}$ statistical package.

\section{RESULTS AND DISCUSSION}

The environmental condition during the tests showed no significant differences between treatments. Temperatures of $23.4 \pm 0.94^{\circ} \mathrm{C}$, dissolved oxygen $6.3 \pm 0.98 \mathrm{mgL}^{-1}$, pH $7.4 \pm 0.17$ and alkalinity of $55 \pm 7.5 \mathrm{mgL}^{-1} \quad \mathrm{CaCO}_{3}$, are suitable parameters for the pejerrey (Piedras et al., 2009).
Preliminary tests showed that benzocaine concentrations above $120 \mathrm{mgL}^{-1}$ caused deep anesthesia without recovery of animals, and consequent death. These conditions correspond to anesthesia state six according to Storkopf (1993). Moreover, concentrations of benzocaine lower than $40 \mathrm{mgL}^{-1}$ did not cause satisfactory anesthesia effects. In this case, the fish stayed in a pre-induction state (Ross and Ross, 2008). The same occurred with a clove oil concentration of $10 \mathrm{mgL}^{-1}$. On the other hand, clove oil concentrations higher than $75 \mathrm{mgL}^{-1}$ were not tested due to formation of froth, a dilution decrease and increase in water cloudiness.

The effectiveness of benzocaine as an anesthetic for pejerrey fingerlings showed a negative time dependence correlation in induction of anesthesia in relation to concentration (Figure 1).

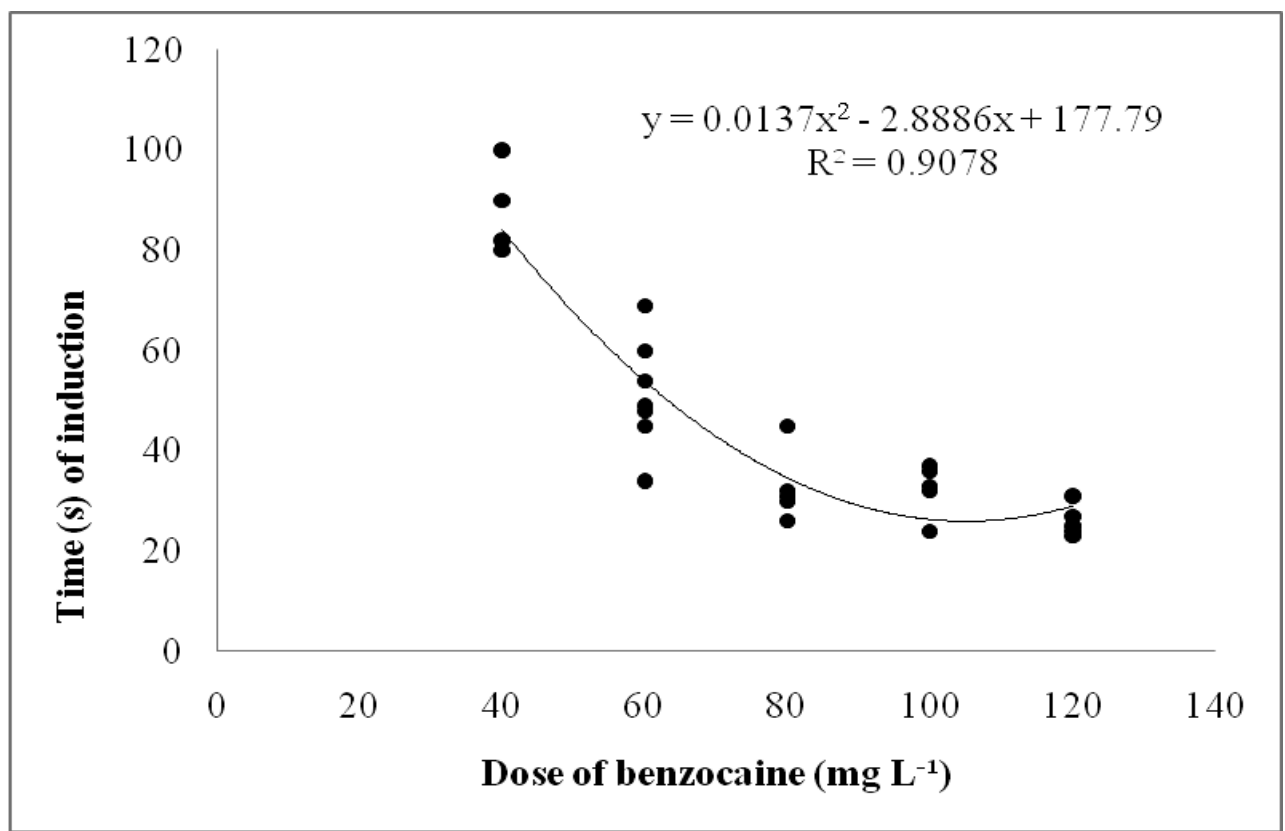

Figure 1. Relation between the dose of benzocaine and anesthesia induction time for pejerrey fingerlings (Odontesthes bonariensis).

The benzocaine dosage that provided the desired anesthetic effect for 30 seconds, as considered satisfactory by Roubach and Gomes (2001) and Iwama et al. (2004) was $87.35 \mathrm{mgL}^{-1}$ (Figure 1). These results are lower than $100 \mathrm{mgL}^{-1}$ reported by Delbon (2006) for tilapia (Oreochromis niloticus), and $125 \mathrm{mg} \mathrm{L}^{-1}$ for lambari (Astyanax altiparanae) (Gimbo et al., 2008). Moreover, Okamoto et al. (2009) established the dosing between 50 and $75 \mathrm{mgL}^{-1}$ of benzocaine for pampo (Trachinotus marginatus) to reach the third stage of anesthesia in 30 seconds. Although 
the values reported for several species are approximate, differences in the concentration of benzocaine, yet small, show the specificity of action of the drug, as suggested by Graham and Iwama (1990) and Iwama et al. (1994).

The concentration of $120 \mathrm{mgL}^{-1}$ of benzocaine resulted in a mortality of $20 \%$ of animals 96 hours after exposure, suggesting that the lethal concentration of this anesthetic for pejerrey is close to this value, this result being similar to $125 \mathrm{mgL}^{-1}$, recorded by Gimbo et al. (2008) for lambari (Astyanax altiparanae). Antunes et al. (2008) argue that the boundaries between the optimal concentration and the lethal concentration of the anesthetic for a given species are very close.

The correlation between the anesthesia induction time and the benzocaine concentration confirms the hypothesis that higher concentrations of anesthetic result in shorter time to reach the desired state of anesthesia. Although this fact is mathematically proven, doses should be considered within physiological limits of this species, because high doses, although not lethal, can lead to metabolic disorders and deleterious effects such as vision and olfactory damage (Barbosa et al., 2007, Okamoto et al., 2009).

Clove oil as an anesthetic for pejerrey fingerlings showed a negative correlation between the product concentration and anesthesia induction time that is represented in Figure 2.

Considering the ideal anesthesia induction time of 30 seconds, the concentration of clove oil resulted in $31.74 \mathrm{mgL}^{-1}$ (Figure 2). This result shows the efficiency of clove oil as an anesthetic for pejerrey fingerlings, confirming the records of $40 \mathrm{mgL}^{-1}$ obtained by Keene et al. (1998) for rainbow trout (Oncorhynchus mykiss), $100 \mathrm{mgL}^{-1}$, recorded by Simões et al. (2010) for tilapia and $50 \mathrm{mgL}^{-1}$ for pampo (Trachinotus marginatus) (Okamoto et al., 2009). There was no mortality on the doses of clove oil tested.

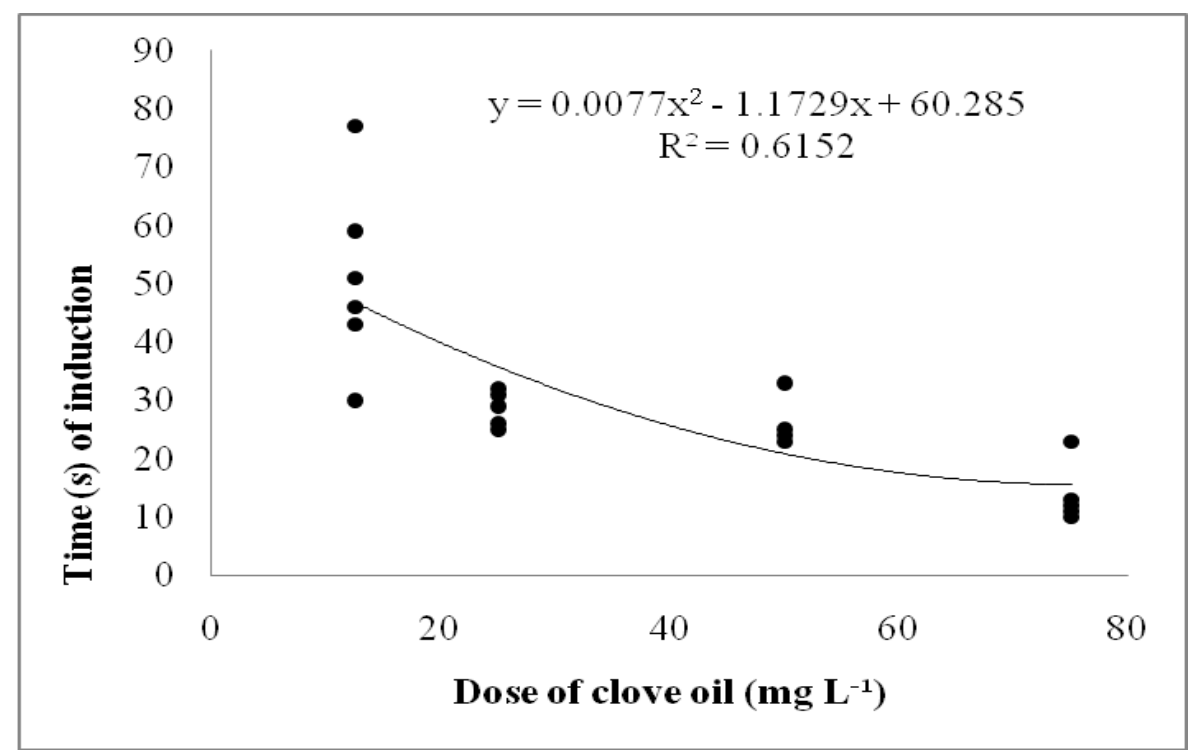

Figure 2. Relation between the dose of clove oil and anesthesia induction time for pejerrey fingerlings (Odontesthes bonariensis).

There is no dependence between dose and recovery time, which had been registered by Gimbo et al. (2008) for lambari (Astyanax altiparanae) exposed to concentrations of 50 to $125 \mathrm{mgL}^{-1}$ of benzocaine. This recovery time is lower than 4 to 7 minutes found by Pereira-DaSilva et al. (2009) for lambari (Astyanax sp.) and
2 to 8 minutes for juvenile pampo (Trachinotus marginatus) found by Okamoto et al (2009).

Although the physiological mechanisms of fish recovery anesthesia are not sufficiently clear, Park et al. (2008) argue that the shorter the induction of anesthesia, the greater the recovery 
time. This rule does not apply to pejerrey because regardless of the concentration and anesthesia induction time, recovery time showed no significant difference. In the case of pejerrey, that can be explained by the fact that its blood cortisol levels are higher (Tsuzuki et al., 2001), which results in a higher gill ventilation and blood oxygenation, therefore these higher cortisol levels shown by pejerrey are not entirely negative.

Lima et al. (2006) discussed stress in fish and said that in certain situations high cortisol levels taken can be beneficial, which can be applied to the pejerrey regarding recovery time from the anesthesia state. On the other hand, Barbosa et al. (2007) studying the physiological effects of clove oil in matrinxã (Brycon amazonicus) reported that clove oil does not reduce the levels of lactate, which is the product of anaerobic glycolysis. The low blood oxygenation caused by the drug does not stop the cellular energetic activity, but reduces it, since anaerobic glycolysis produces less ATP. In pejerrey fingerlings, the recovery time of the anesthesia state was not related to the anesthetic concentration used, because as soon as the blood oxygenation was restored, the metabolic activities returned to the physiological status of the species.

Recovery time for animals exposed to concentrations between 40 and $120 \mathrm{mgL}^{-1}$ of benzocaine showed no significant difference ranging between 38.5 and 48.5, average $40.5 \pm 11.5$ seconds (Table 1 ).

Table 1. Recovery time from the anesthesia state and mortality of pejerrey fingerlings (Odontesthes bonariensis) submitted to benzocaine and clove oil.

\begin{tabular}{lccccc} 
& \multicolumn{7}{c}{ Benzocaine } \\
\hline $\begin{array}{l}\text { Concentration } \\
\left(\mathrm{mg} \mathrm{L}^{-1}\right)\end{array}$ & 40 & 60 & 80 & 100 & 120 \\
\hline $\begin{array}{l}\text { Recovery } \\
\text { time (s) }\end{array}$ & $38.5 \pm 14.4$ & $48.5 \pm 9.1$ & $47.2 \pm 9.6$ & $46,8 \pm 10.7$ & $48.3 \pm 11.3$ \\
Mortality (\%) & 0 & 0 & 0 & 0 & 20 \\
\hline & 12 & Clove Oil & 50 & 75 \\
\hline $\begin{array}{l}\text { Concentration } \\
\left(\text { mg L }^{-1}\right)\end{array}$ & $115 \pm 16.5$ & $151.0 \pm 36$ & $131.5 \pm 40.5$ & $132 \pm 50.7$ \\
$\begin{array}{l}\text { Recovery } \\
\text { time (s) }\end{array}$ & 0 & 0 & 0 & 0 \\
Mortality (\%) & 0 & 0 & 0 \\
\hline
\end{tabular}

Similar to what occurred with benzocaine, the animals exposed to clove oil at concentrations between 12 and $75 \mathrm{mgL}^{-1}$ presented no significant differences in recovery time from the anesthesia state. The average recovery time was $132.03 \pm 37.8$ seconds, ranging from 115 to 151 seconds.

\section{CONCLUSIONS}

The benzocaine and clove oil are effective as anesthetics for pejerrey fingerlings, providing suitable conditions for the handling of animals in research activities. The recovery of the anesthesia state is satisfactory without the occurrence of mortality, if concentrations between 80 and $100 \mathrm{mgL}^{-1}$ of benzocaine and between 25 e $50 \mathrm{mgL}^{-1}$ of clove oil are used. In the continuing quest for knowledge of this species, further studies are needed to evaluate the use of anesthetics in adults. Also, it is important to evaluate side effects that may produce stress, causing physiological, behavioral, reproductive changes in performance, which are still unknown.

\section{REFERENCES}

APHA. Standard Methods for the Examination of Water and Wastewater. 20.ed. Chicago, USA: American Public Health Association, 1998. $1325 \mathrm{p}$.

ANTUNES, M.I.P.P.; SPURIO, R.S.; GODOI; D.A. et al. Benzocaine hydrochloride anesthesia in carp (Cyprinus carpio). Semina: Ciências Agrárias, v.29, p.51-156, 2008. 
BALDISSEROTTO, B. Freshwater fish culture in Rio Grande do Sul State: Actual situation, problems and future perspectives. Cienc. Rural, v.39, p.291-299, 2009.

BARBOSA, L.M.G.; MORAES, G.; INOUE, L.A.K.A. Metabolic responses of matrinxã to eugenol in anesthetic baths. Acta Sci., Biol. Sci., v.29, p.255-260, 2007.

BRAZIL. Law 11,794 of October 8, 2008. Regulates item VII of $\S 1$ of art. 225 of the Federal Constitution, establishes procedures for the scientific use of animals, repealing the 6,638 Act of May 8, 1979, and other measures. Available <https://www.in.gov.br/imprensa/visualiza/> Accessed Oct. 10, 2008.

DELBON, M.C. 2006 Ação da benzocaína e do óleo de cravo sobre parâmetros fisiológicos de tilápia, Oreochromis niloticus. Jaboticabal. 87p. (Dissertação de mestrado em Aquicultura. Universidade Estadual Paulista Júlio de Mesquita Filho, UNESP). Disponível em: <www.caunesp.unesp.br>

GALHARDO, L.; OLIVEIRA, R. Animal welfare: a legitimate concept for fish? Rev. Etologia, v.8, p.51-61, 2006.

GIMBO, R.Y.; SAITA, M.V.; GONÇALVES, A.F.N. et al. Different benzocaine concentrations on anesthetic induction in lambari ("Astyanax altiparanae"). Rev. Bras. Saúde Prod. Anim., v.9, p.350-357, 2008.

GRAHAM, M.; IWAMA, G.K. The Physiologic effects of the anesthetic ketamine hydrochloride on two salmonid species. Aquaculture, v.90, p.323-331, 1990.

IWAMA, G.K.; ACKERMAN, A. Anesthetics. In: HOCHACHKA, P.; MOMMSEN, J. Analytical techniques in biochemistry and molecular biology of fishes. Elsevier Science, Amsterdam, v.3, 1994. p.1-5.

IWAMA, G.K.; AFONSO, L.O.B.; VIJAYAN, M.M. Stress in Fish. AquaNet Workshop on Fish Welfare, Campbell River, Canada, 2004. p.1-9.

KEENE, J.L.; NOAKES, D.L.G.; MOCCIA, R.D. et al. The efficacy of clove oil as an anesthetic for rainbow trout, Oncorhynchus mykiss (Walbaum). Aquaculture Res., v.29, p.89101, 1998.
LIMA, L.C.; RIBEIRO, L.P.; LEITE, R.C. et al. Stress in fishes. Rev. Bras. Reprod. Anim., v.30, p.113-117, 2006.

MOREIRA, P.S.A.; VOLPATO G.L. Conditioning of stress in Nile tilapia. J. Fish Biol., v.64, p.961969, 2004.

OKAMOTO, M.H.; TESSER, M.B.; LOUZADA, L.R. et al. Benzocaine and eugenol as anaesthetics for pompano juvenile Trachinotus marginatus. Cienc. Rural, v.39, p.866-870, 2009.

PARK, M.O.; HUR, W.J.; IM, S.Y. et al. Anaesthetic efficacy and physiological responses to clove oil anaesthetized kelp grouper Epinephelus bruneus. Aquaculture Res., v.39, p.877-884, 2008.

PEREIRA-DA-SILVA, E.M.; OLIVEIRA, R.H.F.; RIBEIRO, M.A.R. et al. Anesthetic effect of clove oil on lambari. Ciência Rural, v.39, p.1851-1856, 2009.

PIEDRAS, S.R.N.; POUEY, J.L.O.F.; MAOTOYAMA, I.S. et al. Survival of embryos of pejerrey Odontesthes bonariensis and Odontesthes humensis at different concentration of salinity. Biotemas, v.22, p.235-238, 2009.

ROSS, L G.; ROSS, B. Anesthetic and sedative techniques for aquatic animals. 2. ed. Oxford, England, UK: Blackwell Science, 1999. 159p.

ROSS, L.G.; ROSS, B. Anesthetic and sedative techniques for aquatic animals. 3.ed. Oxford, England, UK: Blackwell Science, 2008. 228p.

ROUBACH, R.; GOMES, L.C. Use of anesthetics in the management of fish. Rev. Panorama Aquicult., v.11, p.37-40, 2001.

SIMÕES, L.N.; PAIVA, G.; GOMES, L.C. Clove oil as an anesthetic on Nile tilapia adults. Pesq. Agropec. Bras., v.45, p.1472-1477, 2010.

STORKOPF, M. Anaesthesia. In: BROWN, L. Aquaculture for Veterinarians: fish husbandry and medicine. London. UK: Pergamon Veterinary Handbook Series, 1993. p.161-168.

TSUZUKI M.Y.; OGAWA I.K.; STRUSSMANN C.A. et al. Physiological responses during stress and subsequent recovery at different salinities in adult pejerrey Odontesthes bonariensis. Aquaculture, v.200, p.349-362, 2001. 